\title{
Sexually Dimorphic Morphological Characters in Five North Atlantic Deepwater Skates (Chondrichthyes: Rajiformes)
}

\author{
Alexei M. Orlov ${ }^{1}$ and Charles F. Cotton ${ }^{2}$ \\ ${ }^{1}$ Russian Federal Research Institute of Fisheries and Oceanography (VNIRO), 17 V. Krasnoselskaya, Moscow, 107140, Russia \\ ${ }^{2}$ Department of Fisheries Science, Virginia Institute of Marine Science, P.O. Box 1346, Gloucester Point, VA 23062, USA
}

Correspondence should be addressed to Alexei M. Orlov, orlov@vniro.ru

Received 16 March 2011; Accepted 9 May 2011

Academic Editor: Jakov Dulčić

Copyright (C) 2011 A. M. Orlov and C. F. Cotton. This is an open access article distributed under the Creative Commons Attribution License, which permits unrestricted use, distribution, and reproduction in any medium, provided the original work is properly cited.

\begin{abstract}
Skates exhibit a variety of manifestations of sexual dimorphism. However, this phenomenon has been poorly documented in deepwater species. New data on the sexual dimorphism of five species of deepwater skates from the North Atlantic Ocean are presented: Amblyraja jenseni, Bathyraja pallida, Bathyraja richardsoni, Rajella bigelowi, and $R$. kukujevi. These skates exhibit sexual dimorphism most frequently in interorbital width, disc length and width, length of the third gill slit, horizontal diameter of the orbit, length of the fifth gill slit, space between the first and fifth gill slits, length of the second dorsal fin base, mouth width, length and width of each lobe of the nasal curtain, distance from the snout to the center of anus, distance from the snout tip to the point of maximum disc width, length of the lateral fold, length of the orbit + spiracle (measured together), tail height at the pelvic fin tips, and the number of median thorns.
\end{abstract}

\section{Introduction}

Skates (Rajoidei) comprise an important component of shelf and continental slope benthic communities of the world's oceans. They are major consumers of cephalopods, decapods, and fishes, often utilizing the same food resources as the apex predators, such as sea birds, marine mammals, and sharks [1]. Skates, like all chondrichthyan fishes, exhibit sexual dimorphism in the structure of the pelvic fins, which in males are modified to act as copulatory organs, or claspers [2]. Also, mature male skates have alar thorns on the edges of the disc, which help to grasp the female during copulation [3-5]. In many species sexual differences have been reported in length, body mass, size and age of sexual maturity, other external morphological features, and diet [3,5-16]. Mature females and males of several skate species exhibit differences in the form and length of the teeth $[3,15,17-23]$. In one species, differences were observed in the shape and size of the shoulder and pelvic girdle [24]. Sexual differences in size and shape of the olfactory and electrical organs have also been found in some skates [3, 25-27]. Even with this variety of manifestations of sexual dimorphism in skates, the phenomenon has been poorly documented in deepwater species. This study presents new data on sexually dimorphic morphological characters of five deepwater skate species from the North Atlantic Ocean: Jensen's skate, Amblyraja jenseni [28]; pale ray, Bathyraja pallida [29]; Richardson's ray, Bathyraja richardsoni [30]; Bigelow's ray, Rajella bigelowi [31]; Mid-Atlantic skate, R. kukujevi [32].

\section{Materials and Methods}

Our comparative analysis of skate morphology was based on the measurement of 45-47 morphometric and 2-15 meristic characters, according to protocols used in recent years [3335]. For some meristic characters (preorbital thorns, postorbital thorns, orbital thorns, interspiracular thorns, and scapular thorns) we observed differences in thorn counts on the left and right side of each specimen. Therefore, we present maximum, minimum, and mean values for one side for each character. The material examined by the authors during 2005-2006 consisted of the majority of specimens of five deepwater skate species available from ichthyological collections worldwide (MCZ-Museum of 
Comparative Zoology, Harvard University, Cambridge, Massachusetts, USA; ZMUB-Zoological Museum, University of Bergen, Bergen, Norway; USNM-National Museum of Natural History, Smithsonian Institute, Washington DC, USA; VIMS-Virginia Institute of Marine Science, Gloucester Point, Virginia, USA; NMSZ-National Museum of Scotland, Edinburgh, Scotland; BMNH-British Museum of Natural History, London, Great Britain; NMHN-Museum National d'Histoire Naturelle, Paris, France; ZISP-Zoological Institute, Sankt-Peterburg, Russia). All measurements were conducted in accordance with conventional procedures [3, 36-38]. The following juvenile, adolescent, and mature specimens were examined (the numbers of females and males, resp., of each species are indicated in parenthesis).

Amblyraja jenseni (7/6)—MCZ 37899, 38354, 55011, 138020-1, 138020-2, 155628; ZMUB 19529, 19462, 19463; VIMS 11757; USNM 35592, 23483, 33457. The USNM specimens were not examined in this study but the morphological data were taken from Bigelow and Schroeder [28, 36, 39].

Bathyraja pallida (3/7)—ZMUB 19465, VIMS 11577, VIMS 11758, NMSZ 2000.130.462, NMSZ 2000.130.80, BMNH 1967.2.13.2, BMNH 1985.11.14.1, BMNH 1985.11.14.2, BMNH 1985.11.14.3, BMNH 1985.11.14.4.

Bathyraja richardsoni (14/13)-BMNH 1999.2.2.1, BMNH 1999.2.2.2, BMNH 1999.2.2.3, BMNH 1999.2.2.4, BMNH 1999.10.1.1, BMNH 1999.10.1.2, NMHN 19991156, NMSZ 2000.130.260, ZMUB 19522-1, ZMUB 19522-2, ZMUB 19522-3, ZMUB 19514-1, ZMUB 19514-2, ZMUB 19514-3, ZMUB 19514-4, ZMUB 19476, ZMUB 17600, ZMUB 19448, ZMUB 19464, ZMUB 19364, ZMUB 19446, ZMUB 19528, ZMUB 19535, VIMS 11756.

Rajella bigelowi (8/10)—NMHN 1988-361, NMHN 1987-482, NMHN 1999-1162; ZMUB 18406, ZMUB 18405; MCZ 55316(A), MCZ 55316(B), MCZ 55316(C), MCZ 58444, MCZ 55314, MCZ 158964, MCZ 57327, VIMS 5562 $(n=3)$, VIMS 8444, VIMS 3347, VIMS 5424.

Rajella kukujevi (2/6)—ZISP 46195, ZMUB 15709, NMHN 1998-0727, NMHN 1999-1165, NMHN 1996-1157, NMHN 1996-1153, NMHN 1996-235, NMHN 1996-1154.

Furthermore, for our comparative analyses of B. richardsoni and $A$. jenseni, we also included published data $[28,30$, $36,39,40]$. We used conventional abbreviations to denote museum collections [41, 42].

Because of the small number of deepwater skates available in ichthyological collections we had an opportunity to examine only 13 specimens of $A$. jenseni, 10 specimens of $B$. pallida, 27 specimens of $B$. richardsoni, 12 specimens of $R$. bigelowi, and eight specimens of R. kukujevi. Since sample size was too small, the statistical significance of the compared material was not evaluated using standard statistical tests. Instead, we evaluated the significance of variation in morphological characters between males and females by comparing the mean $(M)$ and standard error $(m)$ for each set of measurements. If the standard errors of the means did not overlap $(M \pm m)$ between males and females, such differences were considered significant.

\section{Results and Discussion}

Amblyraja jenseni was described in the middle of the past century [28] and since then, several records of this skate have been reported from the North Atlantic [43-47]. Until recently, morphometric and meristic data were limited to three specimens $[28,36,39]$. Although a recent study [35] considerably expanded the knowledge of morphological features of $A$. jenseni, information about sexual dimorphism of this species, until now, was absent.

Our results show that the greatest differences in male and female A. jenseni are found in the disc length, horizontal diameter of the orbit, height of the tail at the pelvic fin tips, length of the third gill slit, space between the fifth gill slits, distances from the center of the anus to the first and second dorsal fins (Table 1).

Bathyraja pallida was described in the second half of the past century [29]. Although there have been eight subsequent specimens collected [34, 45, 48-50], morphometric and meristic data are limited to two specimens, and these accompanied the original description of the species [29]. A recent publication [35] contributed to the existing morphological data available for this species; however, that study did not include information about sexual dimorphism. Furthermore, these data were based on the examination of only three specimens.

Maximum differences between male and female $B$. pallida were found in the following characters (Table 2): interorbital width, interspiracular width, height of the first dorsal fin, lengths of the first and second dorsal fin bases, tail height at the pelvic fin tips, mouth width, nasal curtain length and width, width of each lobe of the nasal curtain, length of first gill slit, space between the first gill slits and the fifth gill slits, distance from the snout tip to the center of the anus, distance from the center of the anus to the tail tip, and the number of teeth in the lower jaw.

The morphological and meristic characters of Bathyraja richardsoni have been examined more thoroughly than most other species in our study. Information on the morphology of 16 mature individuals of this species has been published in several early papers $[30,40,51,52]$. However, these studies omitted many of the morphometric and meristic characters used in our study. More recently [34], a similar measurement scheme on four advanced embryos of this species was used, and the same measurement scheme was used on several specimens caught on the Mid-Atlantic ridge during the MAR-ECO expedition (www.mar-eco.no), as well as material from the BMNH and MNHN collections [35]. Nevertheless, none of these prior studies offer information about sexual dimorphism of $B$. richardsoni.

Our results show $B$. richardsoni to be sexually dimorphic in the following characters (Table 3): disc width, disc length, horizontal diameter of the orbit, length of the orbit + spiracle (measured together), tail width at the pelvic fin tips, length of the lateral fold, mouth width, lengths of the third and fifth gill slits, distance from the snout tip to the center of the anus, distance from the snout tip to the line of maximum disk 


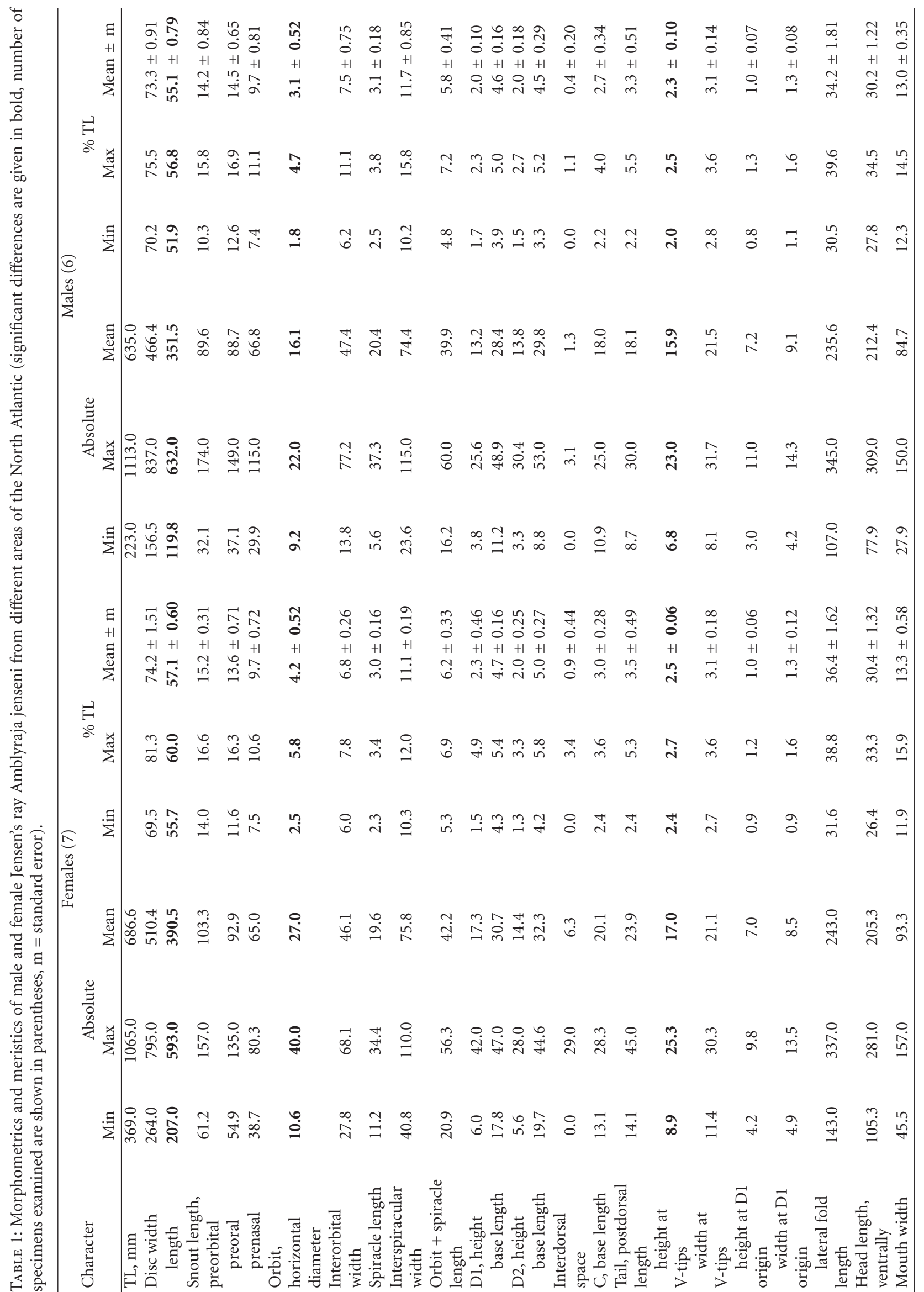




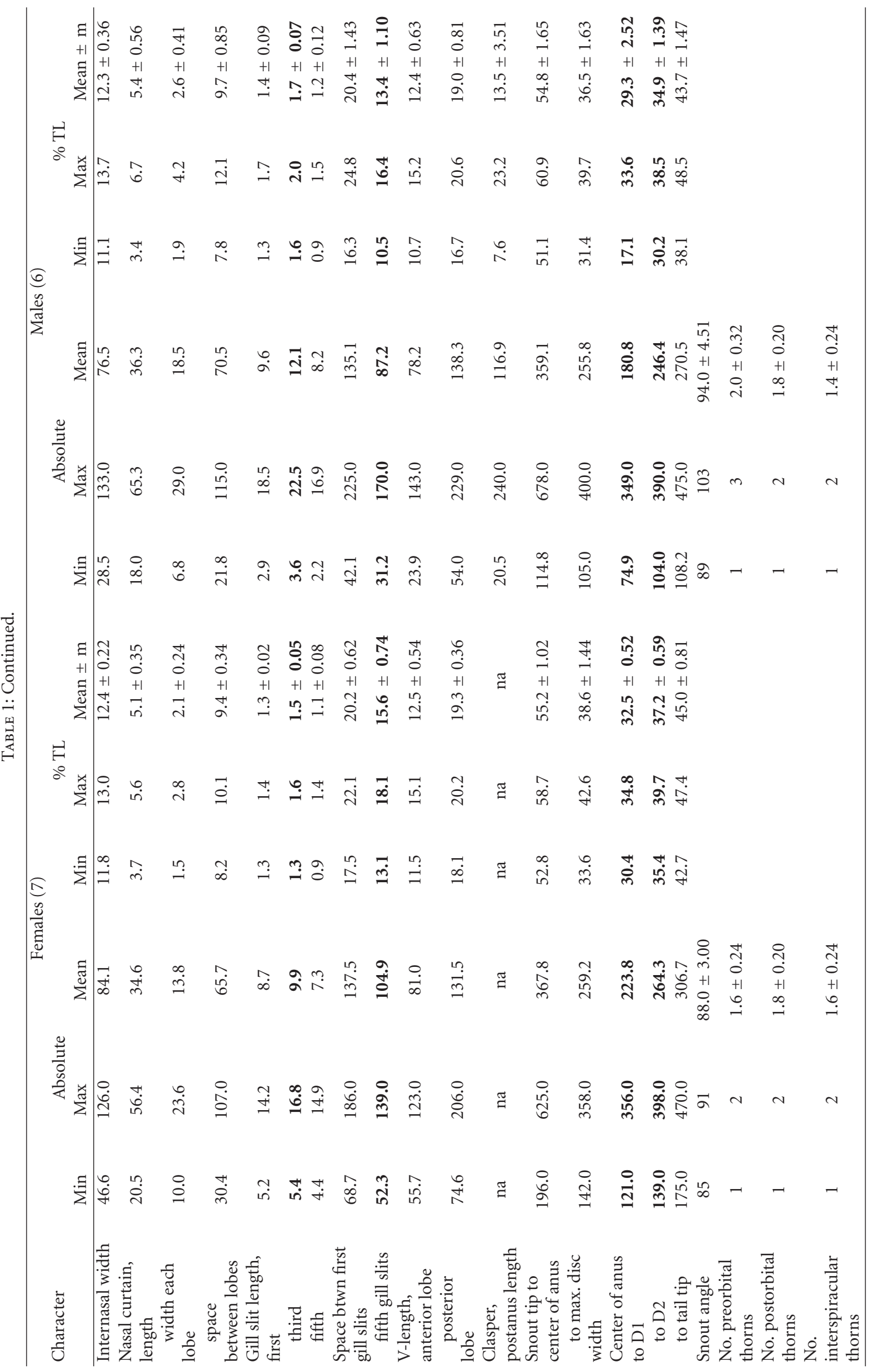




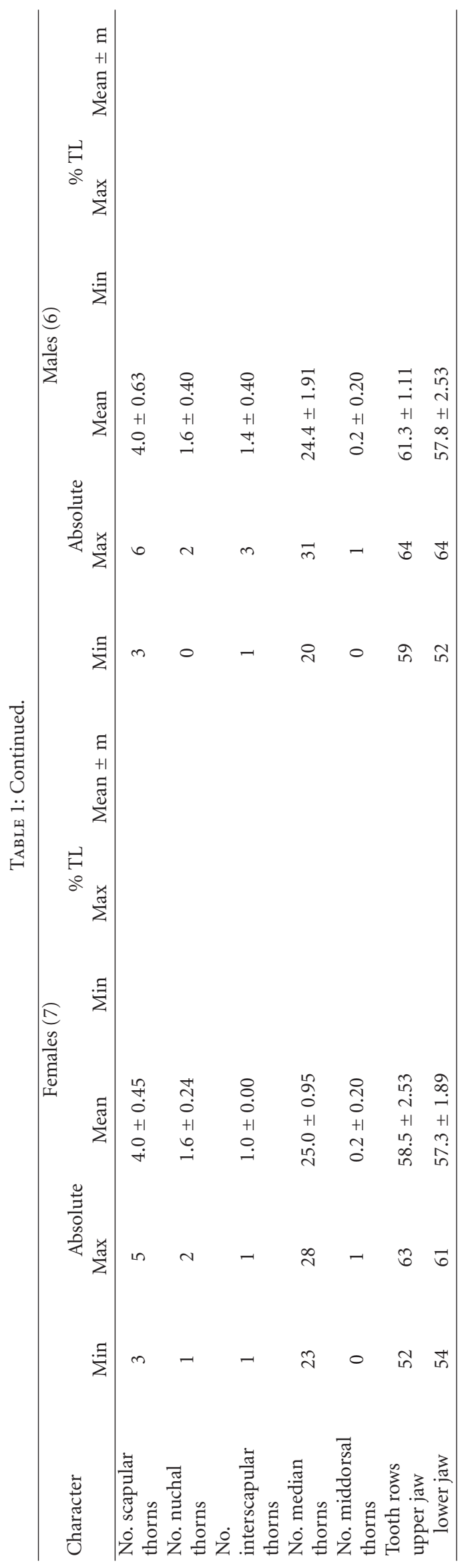




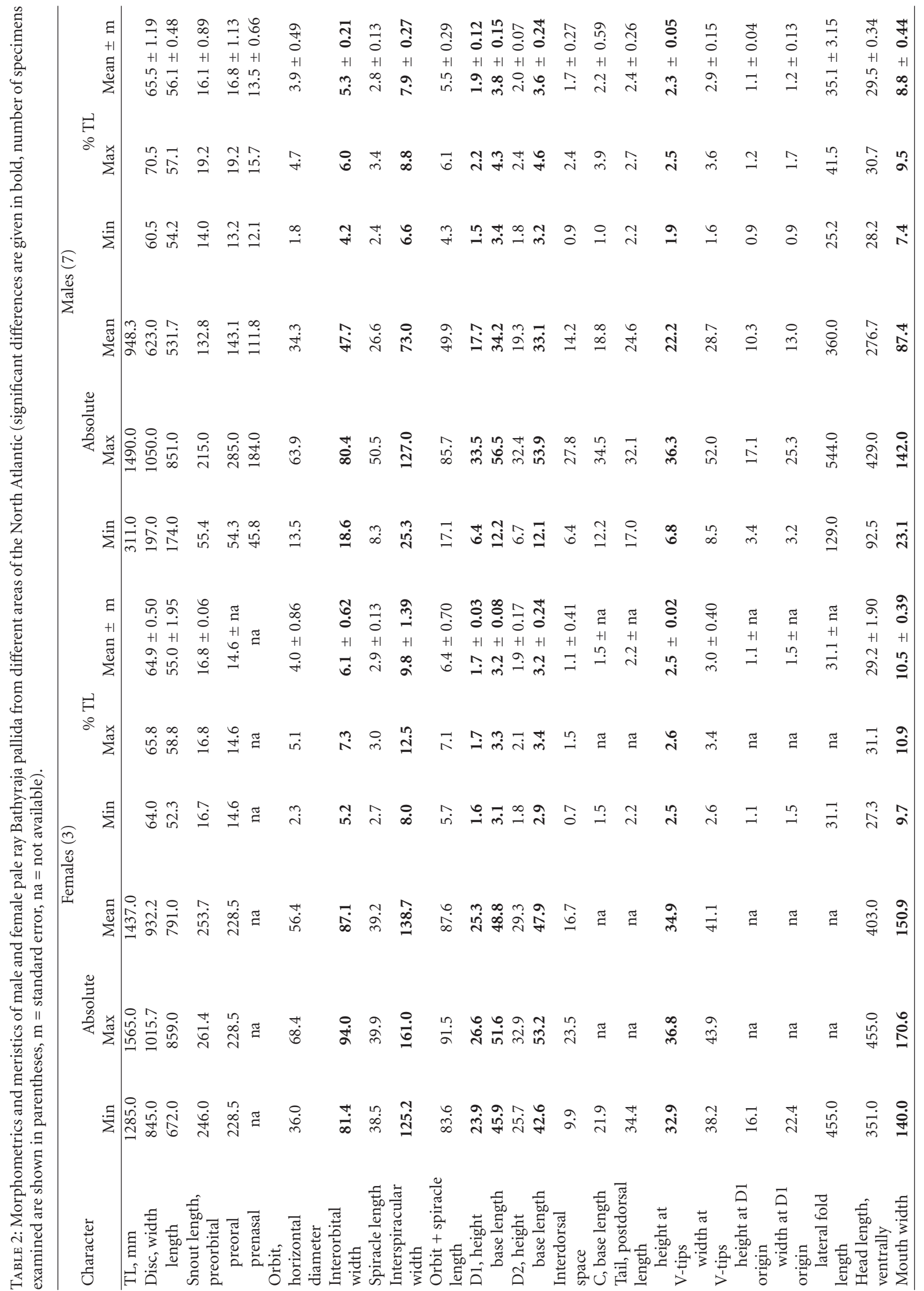




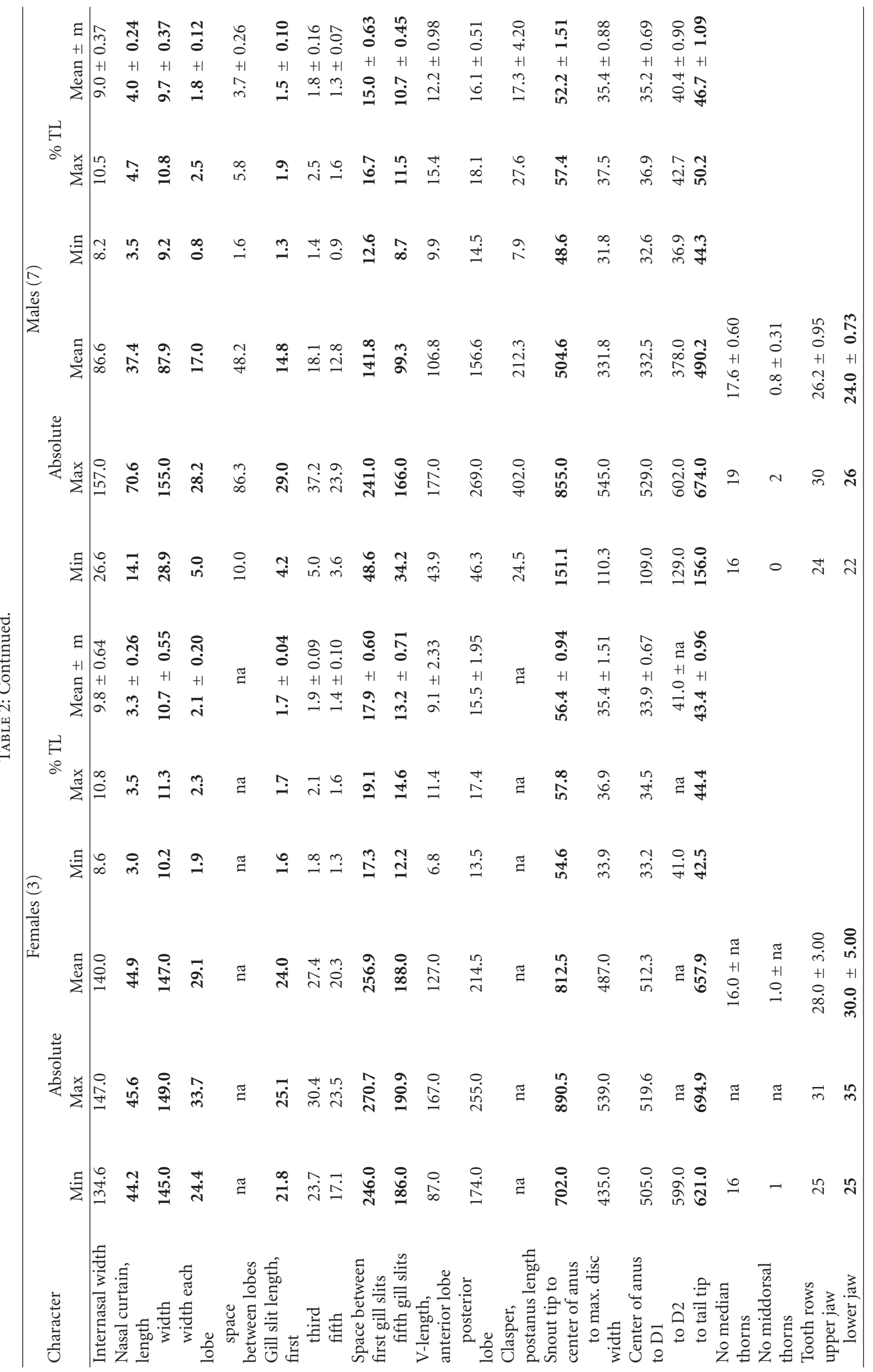




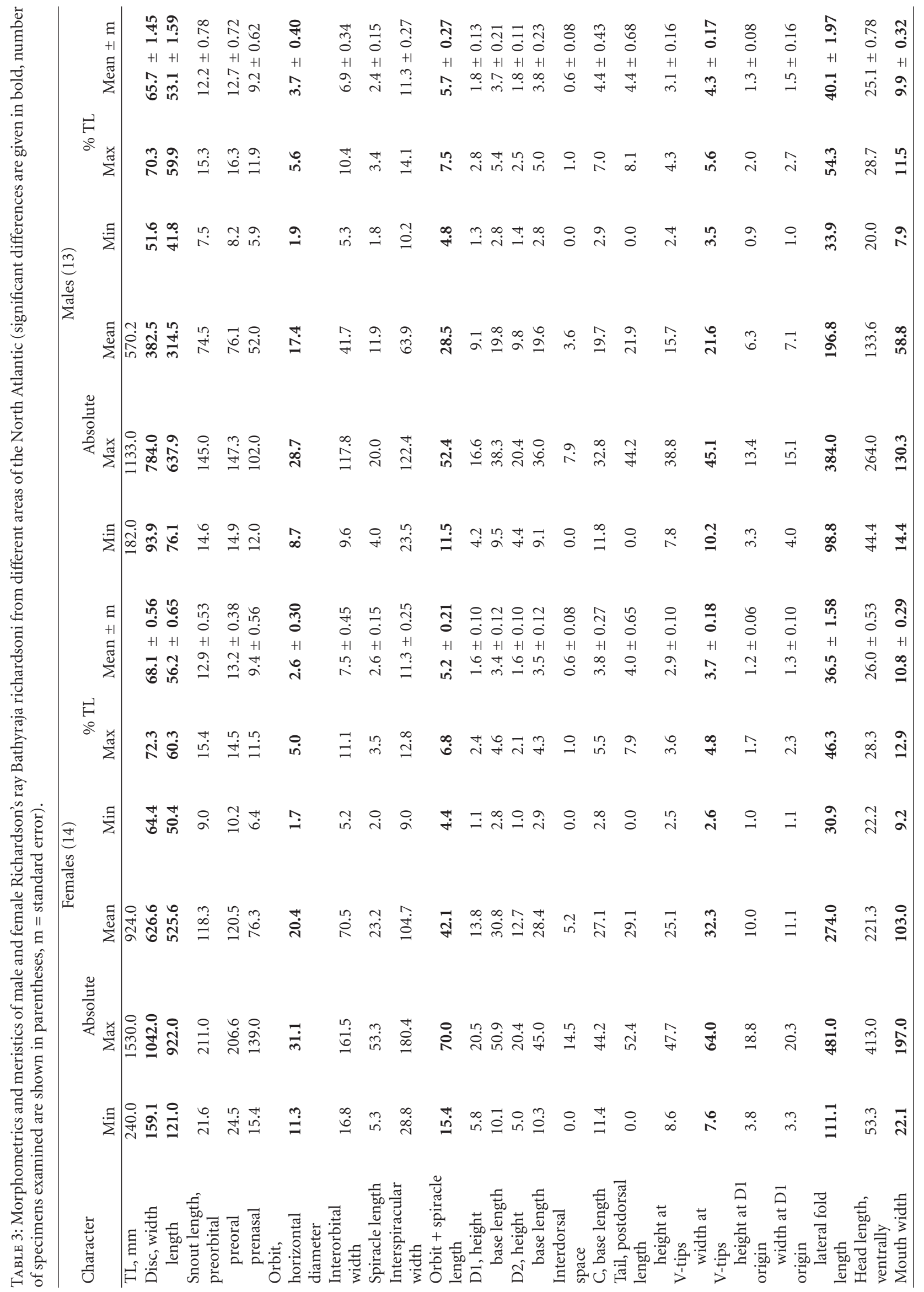




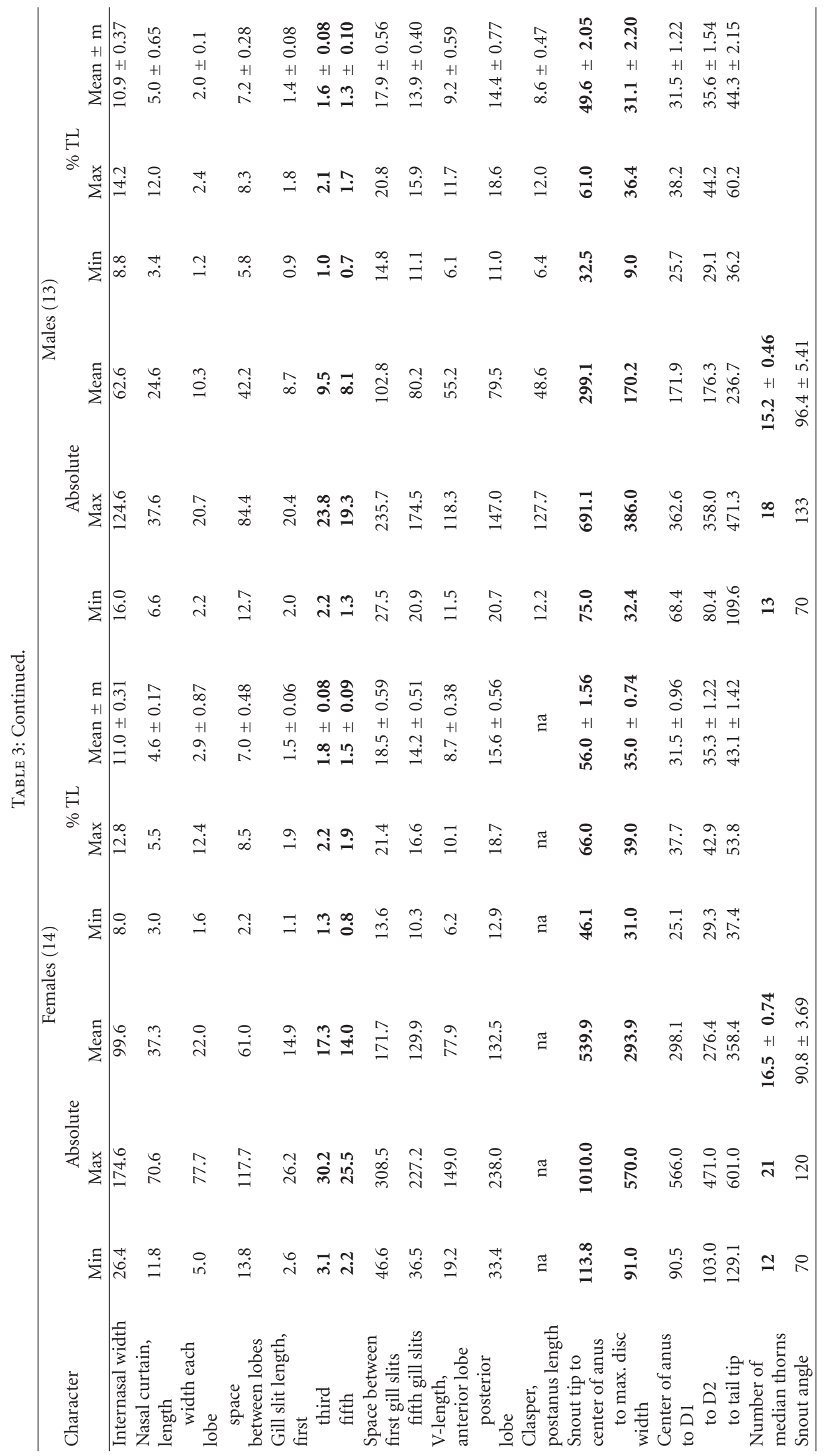




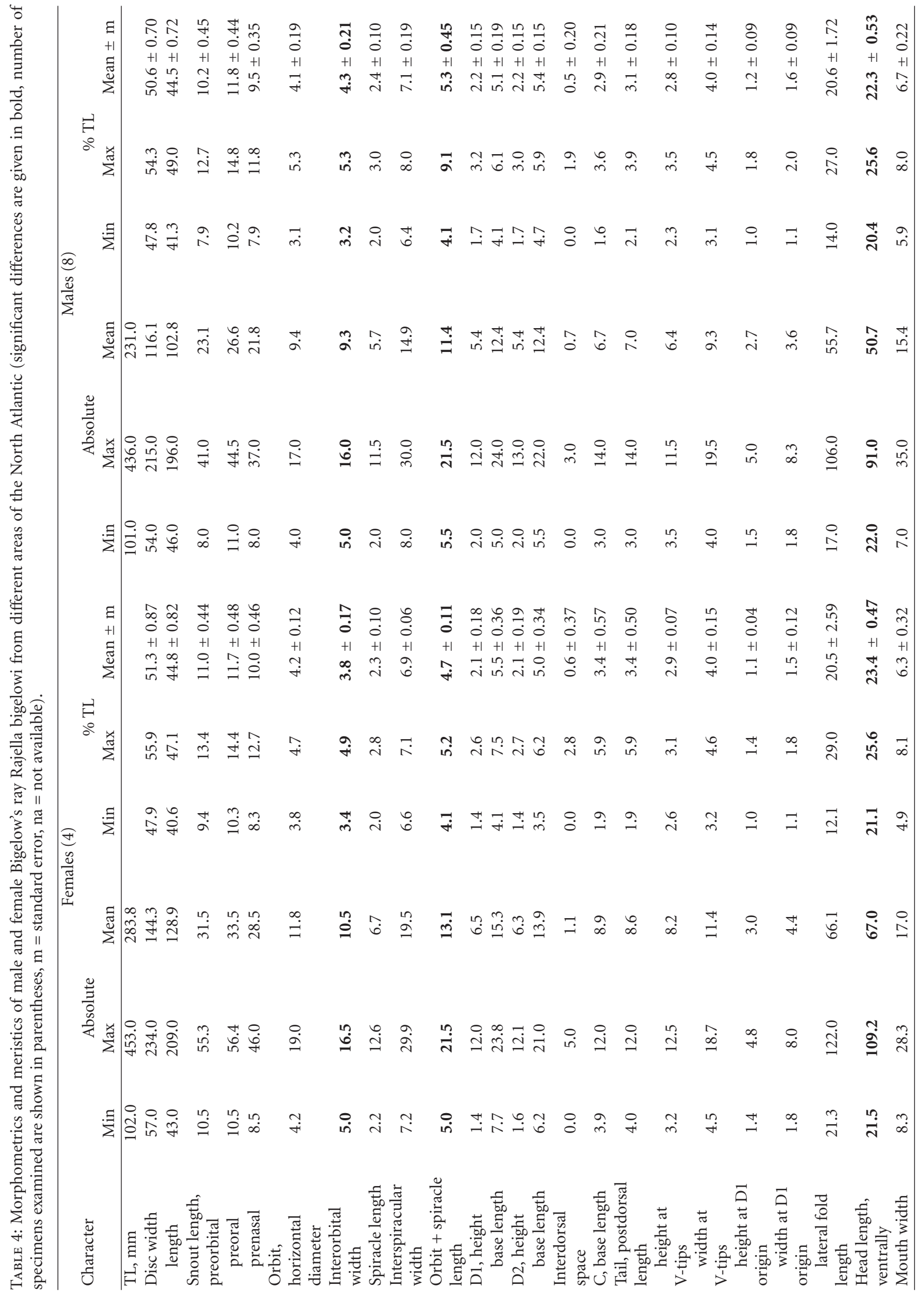




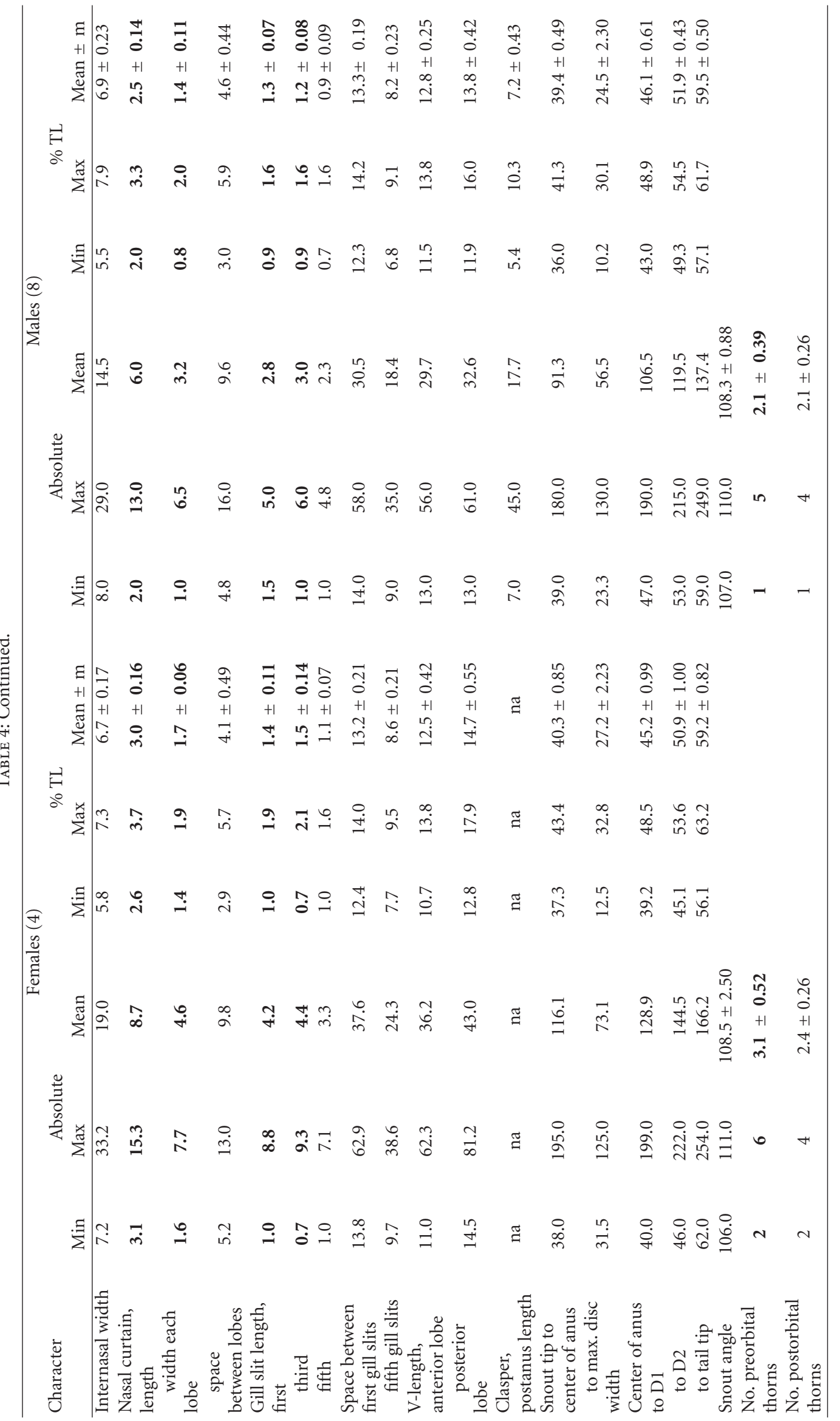




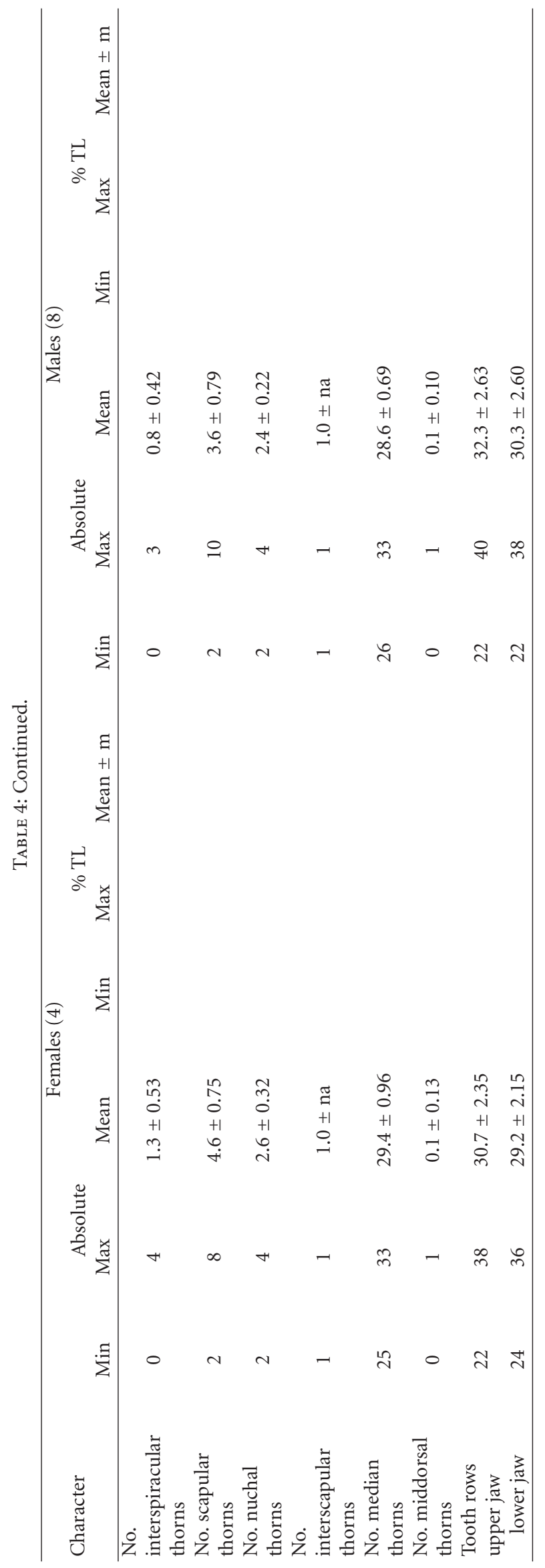




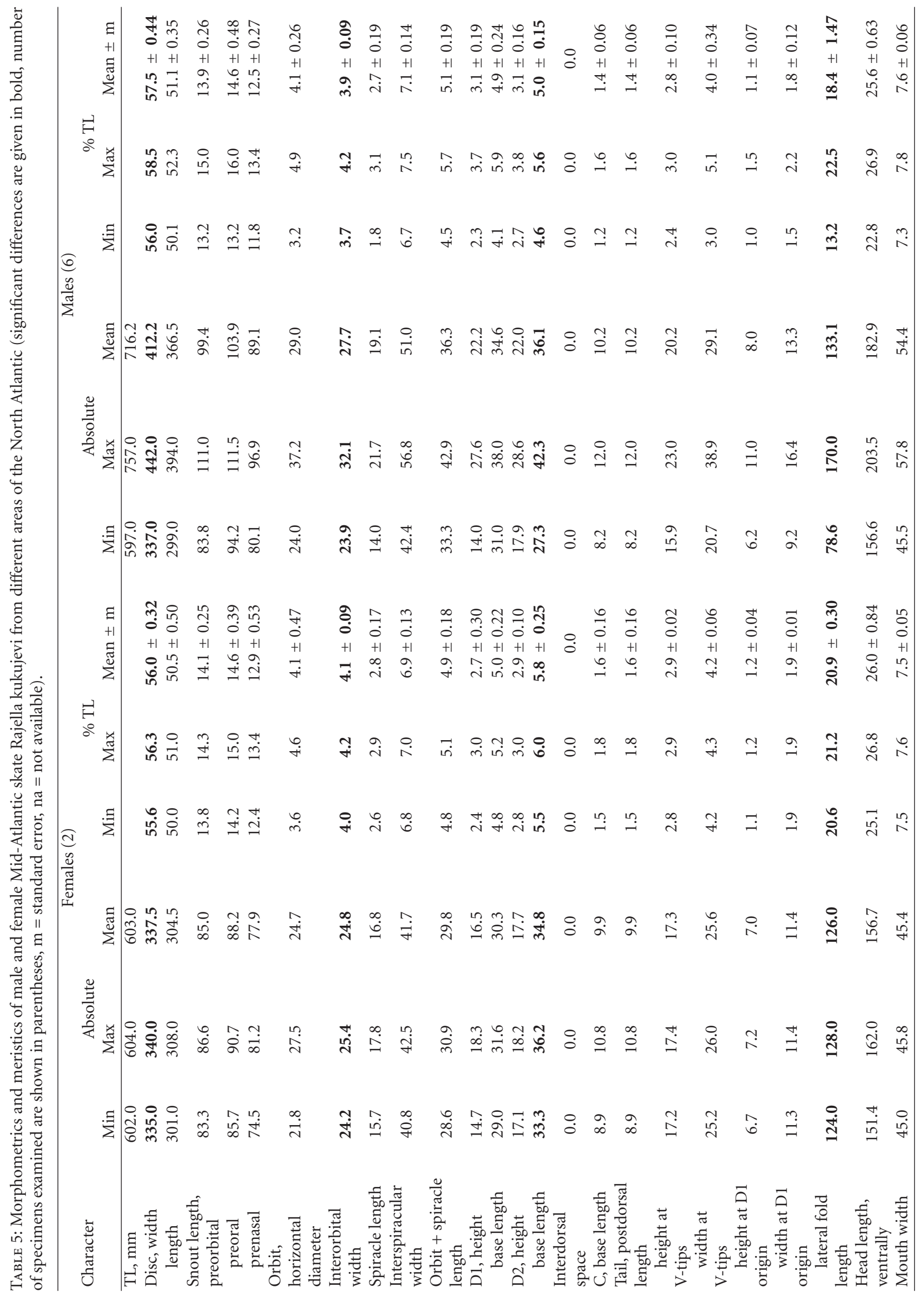




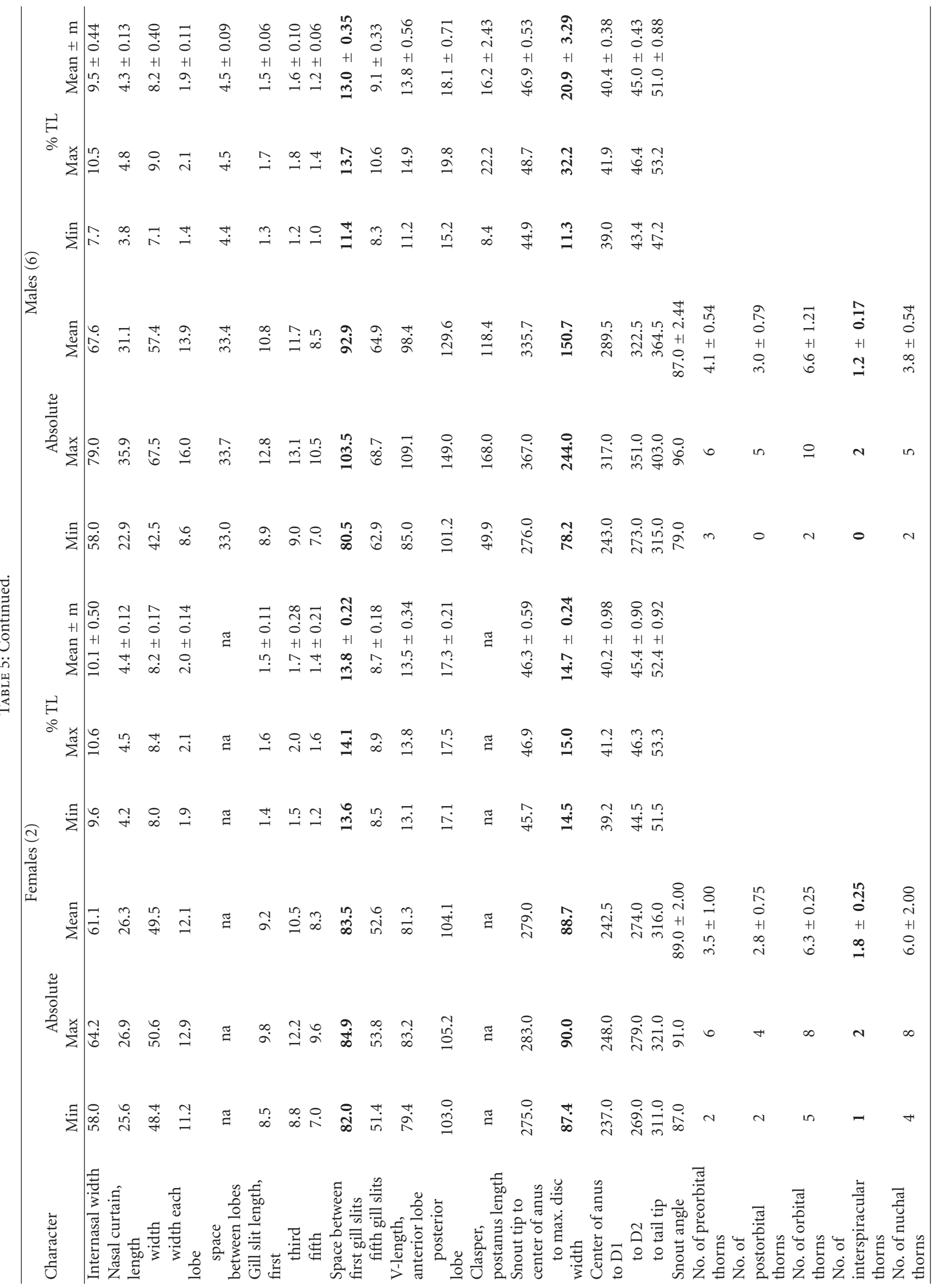




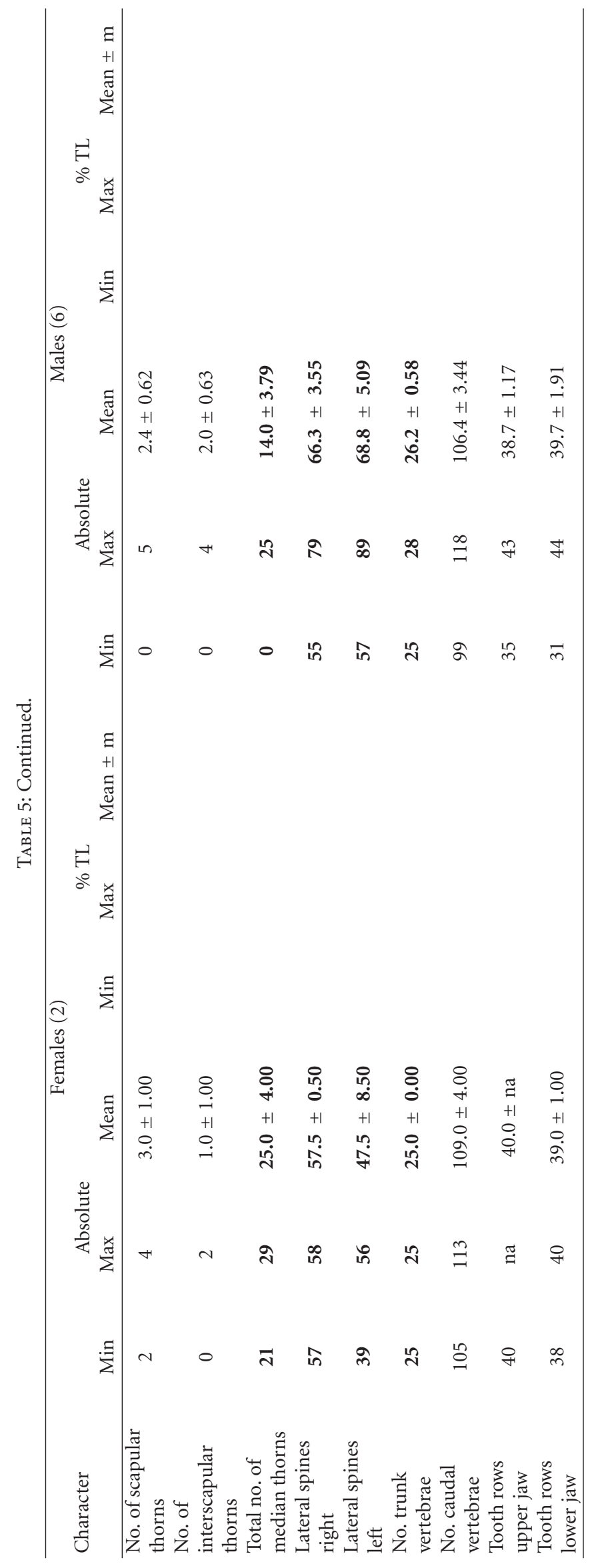


width, and the number of median thorns.

The morphology of Rajella bigelowi has been documented better than all the other species in our study, with published data on 30 specimens $[31,33]$. In a recent study, additional data on the morphology and meristics of $R$. bigelowi from the North Atlantic was provided [35], based on specimens from the MCZ and $\mathrm{MHNH}$ and two neonates collected from the Mid-Atlantic Ridge (ZMUB). However, there have been no investigations concerning the sexual dimorphism of this species. Our analysis of 18 specimens of $R$. bigelowi showed that males and females of this species differ significantly in the following characters (Table 4): interorbital width, length of the orbit + spiracle (measured together), head length, length of the nasal curtain, width of each nasal curtain lobe, length of the third and fifth gill slits, and the number of preorbital thorns. Some of the thorn counts for this species varied on the left and right sides of the specimen (i.e., orbital thorns, scapular thorns, etc.). Therefore, the maximum, minimum, and mean values for these characters are shown for one side of the animal. Apparent sexual dimorphism of meristic characters could be due to our small sample size or low variation among the specimens observed.

Morphometric and meristic data from Rajella kukujevi are published in a single paper, which is the original description of the species [32]. Unfortunately the description of this species included only a small number of characters. Since then, only three specimens have been collected [50,53], but these subsequent records lack any reporting of morphometric or meristic data. Therefore, the morphology of this species has been scantly reported and no data on sexual dimorphism are available.

The males and females we examined differ in the following characters (Table 5): disc width, interorbital width, length of the second dorsal fin base, lateral fold length, space between the first gill slits, distance between the snout and the point of maximum disc width, number of interspiracular and median thorns, number of lateral spines on the right and left sides of the tail, and the number of trunk vertebrae. Like $R$. bigelowi, the apparent sexual dimorphism of meristic characters could be due to our small sample size (only two females examined) or low variation among the specimens observed. Conversely, other characters might be sexually dimorphic but not detected by our analysis, owing to very high variation in some characters (i.e., median thorns and lateral spines). Also, like R. bigelowi, the maximum, minimum, and mean values for some of the thorn counts were given for one side of the animal.

Studies of sexual dimorphism in batoids are limited. However, these previous studies found sexual dimorphism in various morphological characters. For example, males and females of the South American apron ray, Discopyge tschudii, and Patagonian skate, Bathyraja macloviana, differ in disc length $[15,26]$. Male and female zipper sand skates, Psammobatis extenta, from Argentinean waters exhibit sexual dimorphism in the prenasal snout length, distance between the anus and tail tip, and distance between the snout tip and anus [14]. The thorny skate, Raja clavata, from the Adriatic Sea exhibits sexual dimorphism in the disc length and maximum eye diameter [6]. Also, many North Pacific skate species from Japanese waters have shown sexual dimorphism in snout lengths, lengths of the pelvic fins, and tail lengths [3].

Our study shows that North Atlantic deepwater skates from the genera Amblyraja, Bathyraja, and Rajella exhibit sexual dimorphism most frequently in the following characters: interorbital width and length of the third gill slit (three of five species), disc length and width, horizontal diameter of the orbit, length of the fifth gill slit, space between first gill slits, space between fifth gill slits, length of the second dorsal fin base, mouth width, length and width of each lobe of the nasal curtain, distance from the snout tip to the center of the anus, distance from the snout to the point of maximum disc width, length of lateral fold, length of the orbit + spiracle (measured together), tail height at the pelvic fin tips, and the number of median thorns (two of five species).

Sexual dimorphism in disc length and the distance from the snout tip to the anus has been noted for other skate species $[6,14,15,26]$. This is probably due to the larger size attained by females, compared to males of the same age $[8-11,16]$. The same reason may cause differences between males and females in the length of the lateral fold, distance from the snout tip to the point of maximum disc width, and the number of median thorns.

Our study shows that females of some species have a relatively wider disc compared to males and this is likely responsible for the observed differences in interorbital width, length of gill slits, length of the orbit + spiracle (measured together), and the space between the gill slits. Differences in mouth width in some species may be caused by sexual dimorphism of the shape and number of teeth in adult skates, as well as differences in diet [3, 9-11, 15, 17-23]. The same cause might be responsible for differences between males and females in size of the nasal curtain.

We also observed differences between males and females in the tail height at the tips of pelvic fins. Since the tail is used in courtship and copulation, it is reasonable to assume that these differences can be attributed to reproductive behaviour.

Forster [37] noted the existence of minor sexual differences in colour patterns of Bathyraja richardsoni that may be related to limited observations (single male and single female examined) and is likely attributable to individual variation. Our study did not reveal significant differences in colouration between males and females in any of the five species examined. However, ontogenetic changes in colour pattern were observed in four of the five species (A. jenseni, B. pallida, B. richardsoni, $R$. bigelowi), while $R$. kukujevi demonstrated considerable individual variation in colouration.

\section{Acknowledgments}

This paper would not have been possible without the input of our many colleagues. Matthias Stehmann (ICHTHYS, Hamburg, Germany) helped with the ID of skates. James Orr (Alaska Fisheries Science Center, Seattle, USA) and Hajime Ishihara, (W \& I Associates Corporation, Fujisawa, Japan) 
explained some specific measurements. Romain Causse (Museum National d'Histoire Naturelle, Paris, France) made $\mathrm{X}$-ray images of Rajella kukuevi and $R$. bigelowi from museum specimens. Ingvar Byrkjedal, (Zoological Museum, University of Bergen, Bergen, Norway), Bernard Séret, (Museum National d'Histoire Naturelle, Paris, France), Karsten Hartel and Andy Williston, (Museum of Comparative Zoology, Harvard, USA), Patrick Campbell and Roberto Miguez, (British Museum of Natural History, London, Great Britain), Geoff Swinney, (National Museums of Scotland, Edinburgh, Scotland), and Monty Priede, (Oceanlab, University of Aberdeen, Newburgh, Scotland) made possible the examination of museum material and provided the facilities and equipment for these analyses. Boris Shieko (Zoological Institute Russian Academy of Science, St. Petersburg, Russia) made measurements of the R. kukujevi holotype. Natalia Popova (VNIRO) made the merisitic calculations from X-ray images. The authors are grateful to these colleagues for their valuable contributions to this paper.

\section{References}

[1] D. A. Ebert and J. J. Bizzarro, "Standardized diet compositions and trophic levels of skates (Chondrichthyes: Rajiformes: Rajoidei)," Environmental Biology of Fishes, vol. 80, no. 2-3, pp. 221-237, 2007.

[2] N. N. Gurtovoj, B. S. Matveev, and F. Ya. Dzerzhinskij, Practical Zootomy of Vertebrates (Lower Chordates, Agnatha, Fish). Handbook for Biological Specialities of Universities, Vysshaya Shkola, Moscow, Russia, 1976.

[3] R. Ishiyama, "Studies on the rajid fishes (Rajidae) found in the waters around Japan," Journal of the Shimonoseki College of Fisheries, vol. 7, pp. 191-394, 1958.

[4] T. C. Tricas, "Courtship and mating-related behaviors in myliobatid rays," Copeia, vol. 3, pp. 553-556, 1980.

[5] J. M. Braccini and G. E. Chiaramonte, "Biology of the skate Psammobatis extenta (Garman, 1913) (Batoidea: Rajidae)," Revista Chilena de Historia Natural, vol. 75, no. 1, pp. 179-188, 2002 (Spanish).

[6] I. Jardas, "The morphometry and population diagnostic of thornback ray, Raja clavata L., in the Adriatic," Acta Adriatica, vol. 17, pp. 1-26, 1975.

[7] P. B. O. Ochumba, "The distribution of skates and rays along the Kenyan coast," Journal of East African Natural History, vol. 78, pp. 26-52, 1988.

[8] C. Capape, J. L. Bouchereau, and J. A. Tomasini, "Occurrence of the devil ray Mobula mobular Bonnaterre, 1788) (pisces, rajiformes, mobulidae) in the Gulf of Aigues-Mortes. Anatomy of pelvic girdle and claspers," Mésogée, vol. 50, pp. 9-14, 1990 (French).

[9] A. M. Orlov, "On feeding of mass species of deep-sea skates (Bathyraja spp., Rajidae) from the Pacific waters of the northern Kurils and southeastern Kamchatka," Journal of Ichthyolo, vol. 38, pp. 635-644, 1998.

[10] A. M. Orlov, "The diets and feeding habits of some deep-water benthic skates (Rajidae) in the Pacific waters off the northern Kuril Islands and southeastern Kamchatka," Alaska Fishery Research Bulletin, vol. 5, pp. 1-17, 1998.

[11] A. M. Orlov, "Diets, feeding habits, and trophic relations of six deep-benthic skates (Rajidae) in the western Bering Sea," Aqua Journal of Ichthyology and Aquatic Biology, vol. 7, pp. 45-60, 2003.
[12] Z. S. Almedia, J. S. Nunes, C. L. Costa et al., "Report of Urotrigon microphthalmum (Elasmobranchii: Urolophidae) from Maranhao (Brazil)'s shallow waters and notes about its biology," Boletin de Investigaciones Marinas y Costeras, vol. 29, pp. 67-72, 2000 (Portuguese).

[13] T. Gedamke, W. D. DuPaul, and J. A. Musick, "Observations on the life history of the barndoor skate, Dipturus laevis, on Georges Bank (Western North Atlantic)," Journal of Northwest Atlantic Fishery Science, vol. 35, pp. 67-78, 2005.

[14] J. M. Braccini and G. E. Chiaramonte, "Intraspecific variation in the external morphology of the sand skate," Journal of Fish Biology, vol. 62, no. 4, pp. 959-972, 2002.

[15] L. B. Scenna, Distribution, abundance and some biological aspects of the Patagonian skate Bathyraja macloviana (Rajidae) from the continental shelf off Argentina and Uruguay, M.S. thesis, Universidad Nacional de Mar del Plata, Mar Del Plata, Argentina, 2003.

[16] N. L. Ruocco, L. O. Lucifora, J. M. Diaz de Astarloa, and O. Wöhler, "Reproductive biology and abundance of the whitedotted skate, Bathyraja albomaculata, in the Southwest Atlantic," ICES Journal of Marine Science, vol. 63, no. 1, pp. 105116, 2006.

[17] A. Feduccia and H. Slaughter, "Sexual dimorphism in skates (Rajidae) and its possible role in differential niche utilization," Evolution, vol. 28, pp. 164-168, 1974.

[18] J. D. McEachran, "Reply to 'sexual dimorphism in skates (Rajidae)," Evolution, vol. 31, pp. 218-220, 1977.

[19] R. M. McCourt and A. N. Kerstitch, "Mating behavior and sexual dimorphism in dentition in the stingray Urolophus concentricus from the Gulf of California," Copeia, vol. 4, pp. 990-991, 1980.

[20] S. M. Kajiura and T. C. Tricas, "Seasonal dynamics of dental sexual dimorphism in the atlantic stingray Dasyatis sabina," Journal of Experimental Biology, vol. 199, no. 10, pp. 22972306, 1996.

[21] S. E. Nordell, "Obervations of the mating behavior and dentition of the round stingray, Urolophus halleri," Environmental Biology of Fishes, vol. 39, no. 3, pp. 219-229, 2005.

[22] T. Gedamke, Developing a stock assessment for the barndoor skate (Dipturus laevis) in the northeast United States, Ph.D. thesis, Virginia Institute of Marine Science, Virginia, Va, USA, 2006.

[23] L. B. Scenna, S. B. Garsia de la Rosa, and J. M. Diaz de Astarloa, "Trophic ecology of the Patagonian skate, Bathyraja macloviana, on the Argentine continental shelf," ICES Journal of Marine Science, vol. 63, no. 5, pp. 867-874, 2006.

[24] M. Stehmann, "Breviraja caerulea spec. nov. (Elasmobranchii, Batoidea, Rajidae); a new deepwater skate and the first record of the genus in the North East Atlantic," Archiv für Fischereiwissenschaft, vol. 27, pp. 97-114, 1976.

[25] S. Waghray, "Olfactory organ and its sexual dimorphism in the electric ray, Narcine timlei (Day)," Indian Journal of Fisheries, vol. 32, pp. 148-151, 1985.

[26] G. Pequeno, R. Navarro, and G. Oporto, "Discopyge tschudii Heckel, 1845: contribution to its taxonomy with emphasis on its sexual dimorphism (Chondrichthyes, Narcinidae)," Estudios Oceanologicos, vol. 7, pp. 41-50, 1988 (Spanish).

[27] J. M. Morson and J. F. Morrissey, "Morphological variation in the electric organ of the little skate (Leucoraja erinacea) and its possible role in communication during courtship," Environmental Biology of Fishes, vol. 80, no. 2-3, pp. 267-275, 2007. 
[28] H. B. Bigelow and W. C. Schroeder, "New and little known cartilaginous fishes from the Atlantic," Bulletin of the Museum of Comparative Zoology, vol. 103, pp. 385-408, 1950.

[29] G. R. Forster, "A new deep-sea ray from the bay of Biscay," Journal of the Marine Biological, vol. 47, pp. 281-286, 1967.

[30] J. A. F. Garrick, "Studies on New Zealand Elasmobranchii. Part XIII. A new species of Raja from 1,300 fathoms," Transactions of the Royal Society of New Zealand, vol. 88, pp. 743-748, 1961.

[31] M. Stehmann, "Raja "bathyphila”, a composite species of the subgenus Rajella: redescription of R. bathyphila Holt and Byrne, 1908 and Raja bigelowi spec. nov. (pisces, rajiformes, rajidae)," Archiv für Fischereiwissenschaft, vol. 29, pp. 23-58, 1978.

[32] V. N. Dolganov, "Raja (Rajella) kukujevi sp.n. (Elasmobranchii, Rajidae) — new skate species from the Mid-Atlantic Ridge," Zoologicheskii Zhurnal, vol. 64, pp. 304-307, 1985 (Russian).

[33] M. Stehmann, "First and new records of skates (Chondrichthyes, Rajiformes, Rajidae) from the West African continental slope (Morocco to South Africa), with descriptions of two new species," Archive of Fishery and Marine Research, vol. 43, pp. 1-119, 1995.

[34] M. F. W. Stehmann and N. R. Merrett, "First records of advanced embryos and egg capsules of Bathyraja skates from the deep north-eastern Atlantic," Journal of Fish Biology, vol. 59, no. 2, pp. 338-349, 2001.

[35] A. Orlov, C. Cotton, and I. Byrkjedal, "Deepwater skates (Rajidae) collected during the 2004 cruises of R.V. "G.O. Sars" and M.S. "Loran" in the Mid-Atlantic Ridge area," Cybium, vol. 30, no. 4, pp. 35-48, 2006.

[36] H. B. Bigelow and W. C. Schroeder, "Sawfishes, guitarfishes, skates and rays," in Fishes of the Western North Atlantic, Part 2, J. Tee-Van, C. M. Breder, A. E. Parr, W. C. Schroeder, and L. P. Schultz, Eds., pp. 1-514, Yale University, New Haven, Conn, USA, 1953.

[37] C. L. Hubbs and R. Ishiyama, "Methods for taxonomic study and description of skates (Rajidae)," Copeia, vol. 3, pp. 483491, 1968

[38] M. Stehmann, "Results of the research cruises of FRV Walther Herwig to South America. LXIV. Bathyraja papilionifera spec. nov. (Pisces, Batoidea, Rajidae), another new skate from the western South Atlantic from the continental slope off northern Argentina," Archiv für Fischereiwissenschaft, vol. 36, pp. 195211, 1985.

[39] H. B. Bigelow and W. C. Schroeder, "Notes on Northwest Atlantic sharks and skates," Bulletin of the Museum of Comparative Zoology, vol. 68, pp. 237-251, 1927.

[40] G. R. Forster, "Raja richardsoni from the continental slope off south-west England," Journal of the Marine Biological Association of the United Kingdom, vol. 45, pp. 773-777, 1965.

[41] A. E. Leviton and R. H. Gibbs, "Standards in herpetology and ichthyology. Standard symbolic codes for institutional resource collections in herpetology and ichthyology," Copeia, vol. 1, supplement 1, pp. 280-282, 1988.

[42] A. E. Leviton, R. H. Gibbs, E. Heal, and C. E. Dawson, "Standards in herpetology and ichthyology: part 1. Standard symbolic codes for institutional resource collections in herpetology and ichthyology," Copeia, vol. 3, pp. 802-832, 1985.

[43] A. H. Leim and W. B. Scott, "Fishes of the Atlantic coast of Canada," Bulletin of the Fisheries Research Board of Canada, vol. 155, pp. 1-485, 1966.
[44] J. D. M. Gordon and J. A. R. Duncan, "Deep-sea bottom-living fishes at two repeat stations at 2,200 and 2,900 $\mathrm{m}$ in the Rockall Trough, northeastern Atlantic Ocean," Marine Biology, vol. 96, no. 3, pp. 309-325, 1987.

[45] J. D. M. Gordon and J. A. R. Duncan, "A note on the distribution and diet of deep-water rays (Rajidae) in an area of the Rockall Trough," Journal of the Marine Biological Association of the United Kingdom, vol. 69, no. 3, pp. 655-658, 1989.

[46] J. C. Quero, P. Lorance, J. Tardy, and E. Tardy, "Ichthyologic observations in 1999 on board research vessel Thalassa," Annales de la Société des Sciences Naturelles de la CharenteMaritime, vol. 8, pp. 1047-1058, 2000 (French).

[47] G. R. Forster, "Line-fishing on the continental slope. II," Journal of the Marine Biological Association of the United Kingdom, vol. 48, pp. 479-483, 1968.

[48] J. A. Moore, K. E. Hartel, J. E. Craddock, and J. K. Galbraith, "An annotated list of deepwater fishes from off the New England region, with new area records," Northeastern Naturalist, vol. 10, no. 2, pp. 159-248, 2003.

[49] M. Stehmann and D. L. Bürkel, "Rajidae," in Fishes of the North-eastern Atlantic and the Mediterranean, P. J. P. Whitehead, M.-L. Bauchot, J.-C. Hureau, J. Nielsen, and E. Tortonese, Eds., vol. 1, pp. 163-196, UNESCO, Paris, France, 1984.

[50] M. W. Clarke, "Records of deep water chondrichthyan fish caught on long-line in the Rockall Trough," Journal of the Marine Biological Association of the United Kingdom, vol. 80, no. 2, pp. 377-378, 2000.

[51] W. Templeman, "The skate, Raja richardsoni Garrick, 1961, assigned to Bathyraja," Journal of the Fisheries Research Board of Canada, vol. 30, pp. 1729-1732, 1973.

[52] W. Templeman, "First records, description, distribution, and notes on the biology of Bathyraja richardsoni (Garrick) from the Northwest Atlantic," Journal of the Fisheries Research Board of Canada, vol. 30, pp. 1831-1840, 1973.

[53] S. P. Iglesias, "Chondrichthyans from the Northeastern Atlantic and the Mediterranean (a natural classification based on collection specimens)," 2006, http://www.mnhn.fr/iccanam/. 

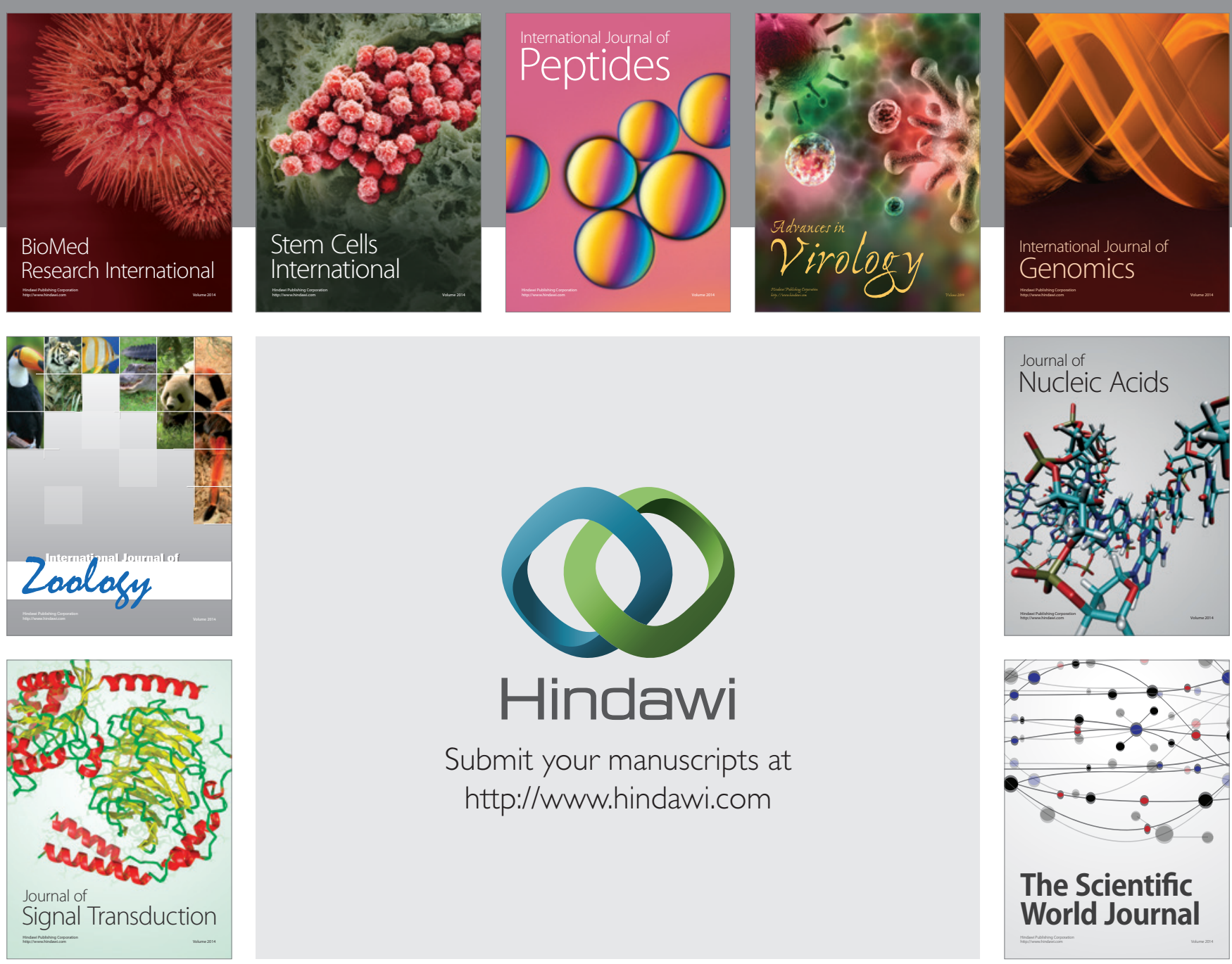

Submit your manuscripts at

http://www.hindawi.com
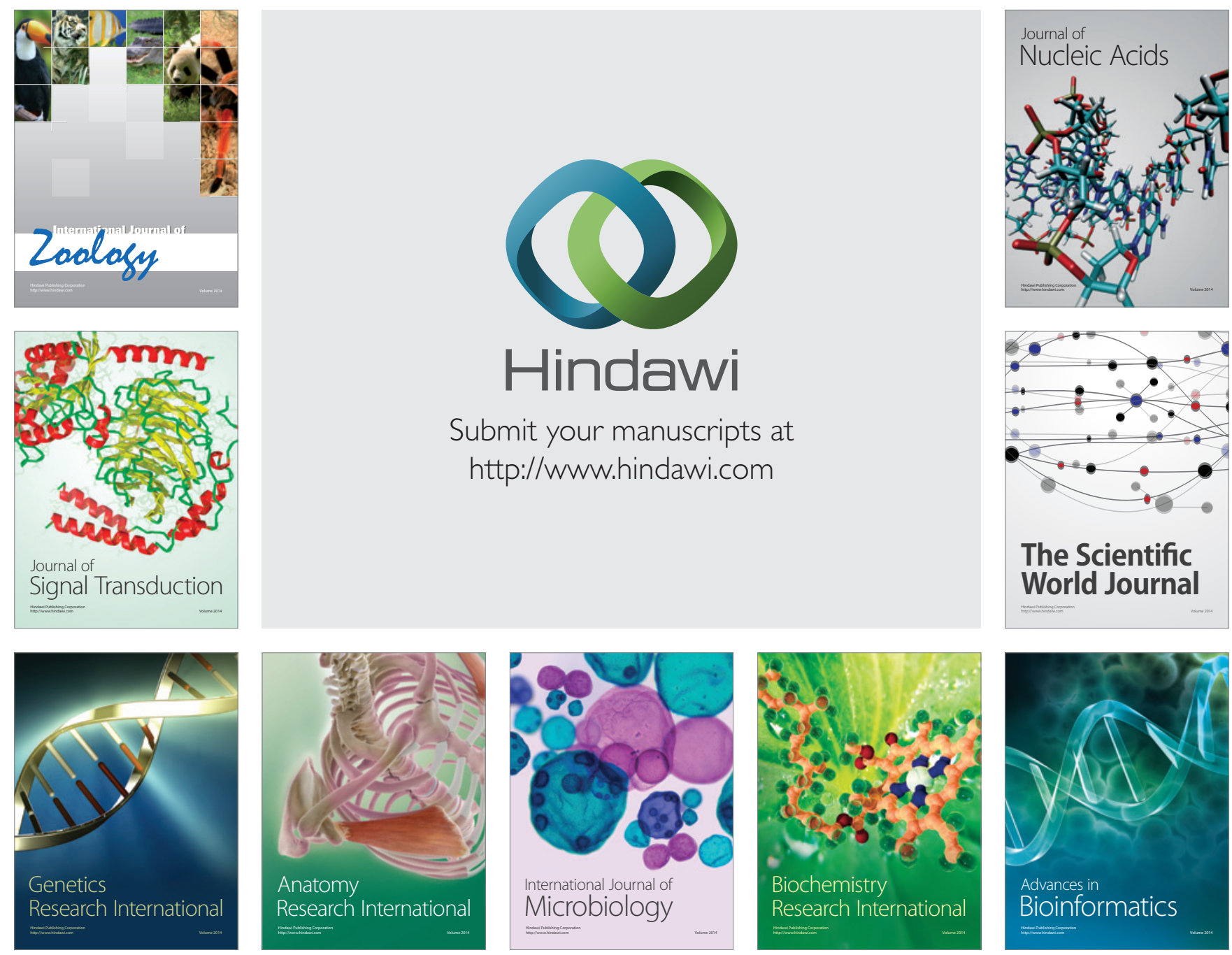

The Scientific World Journal
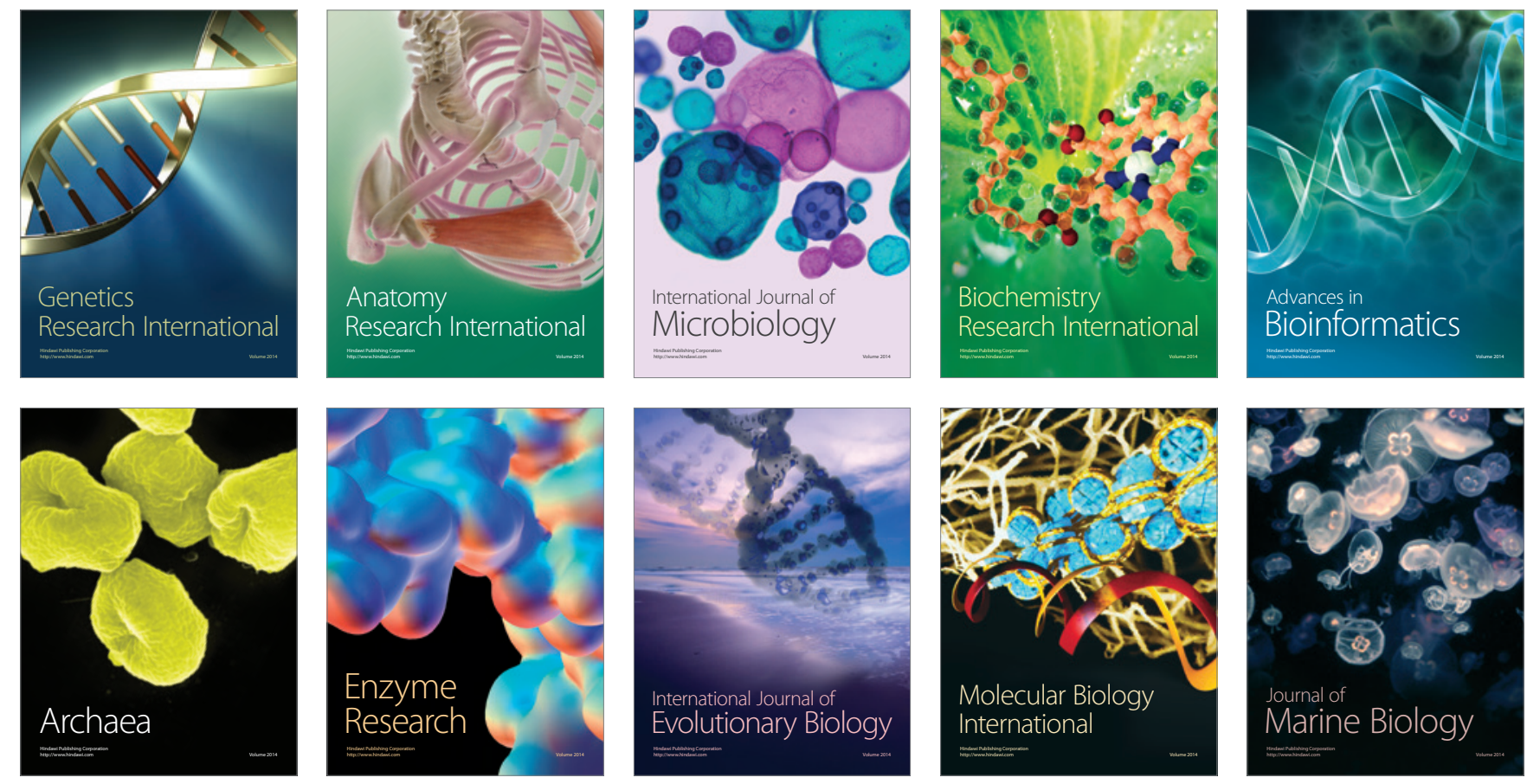